\title{
Business Model for a Post Pandemic Startup In Indian Fast Moving Consumer Goods FMCG sector
}

\author{
Anup Sharma ${ }^{1}$, Sudhir Kumar Arya ${ }^{2}$, Shubham Parekh ${ }^{2}$, Chandrasena Nagendraverma ${ }^{2}$, Nidwan \\ Ebrahim $^{2}$ \\ ${ }^{1}$ Assistant Professor, Lovely Professional University; \\ ${ }^{2}$ MBA Scholar, Lovely Professional University
}

\begin{abstract}
:
The objective of this study was to come up with a Business model for the post-pandemic start-up in the Indian FMCG sectors. For this purpose, a questionnaire was designed to collect the data from various respondents of different gender and age groups. The responses were taken to know what the consumers are preferring and what they choose over at the time of the pandemic. Close-ended questions were prepared to collect the data. The questions included in the questionnaire were designed in such a way that they may give a basic idea of where to hit the ball in the court at the time of the pandemic. We know that COVID-19 has shown us a picture we never thought will ever be there and were not prepared for the same. Therefore, to avoid such kind uncertainties affecting the operations of the well-settled business and also to give confidence to the start-ups that have been affected by the same this study was conducted to know the choice, preference, and other factors affecting the purchasing habits of the consumers. Through the study, we found out that the majority of the consumers are focusing more on their health and are shifting to the products which may help them to build their immunity and keep them immune from the virus. This study can be of great use for start-ups to consider and follow to make sure they grab a huge number of market shares.
\end{abstract}

Keywords: Covid-19, Supply chain, Business model, FMCG

\section{Introduction}

Is the world now seeming to be the same place we used to live before, a dep thought we get? The pandemic has left no area unaffected let it be FMCG, finance, Education, etc. with around 35,659,007 (as of 7 Oct 2020) confirmed cases of COVID-19 and 1,044,269 deaths (WHO) and over 66,23,815 reported cases in India (Govt. of India). Preventive measures had to be taken by the government to control the spread of this deadly virus, the lockdown over the nation was the solution for a preventive measure, as the lockdown was imposed, the global economy also got affected very badly. This reacted in a bad effect on the industries and FMCG was also not safe from this global recession due to COVID-19.

FMCG's are the industry that has been fulfilling the daily needs of their customers daily. The products they manufacture don't have very long shelf lives, they are meant for fast consumption rate, affordable price, and which completely fulfills the daily needs of customers. Being the $4^{\text {th }}$ largest industry in India and contributing over 20\% of the Gross Domestic Product of India consisting of 3 operational product path, Personal Care, Housing and Food and Beverages, where about $50 \%$ of the sales are accounted by Household and Personal Care, $31-32 \%$ for Healthcare and remaining 18-19\% by Food and Beverages (sourceinvestindia.gov.in).

The performance of the FMCG industry in India was quite good with positive growth in sales, and having a recorded revenue of $21.4 \%$ in the last 10 years. The industry changed its face when it saw a huge jump in the growth rate of US\$31.6billion to US\$52.8billion from 2011 to 2018. It was expected that a growth rate of 27.9\% CAGR will be seen in the FMCG sector, which sums to US\$103.7billion by 2020, and the rural 
FMCG market was projected to grow at a rate of $14.6 \%$ CAGR summing to US\$100billion by 2020 and by 2025 (US\$220billion).

Even though the FMCG industry was affected badly, the sales of sanitary products were positive. The industry saw a huge growth in the demands for packaged foods and the essential ration items but due to the lack of the raw materials, the industry failed to satisfy the demands of the consumers as the shelves and inventory were bingo! The Indian FMCG sector will witness a flat growth curve in 2020 due to pandemics, as the industry sees some good numbers in the growth but the negative effect will remain due to the slashed growth forecast of 5-6\% for 2020. The April-June quarter has been the worst nightmare for the industries as the major decline in the sales and profits were recorded at this month the highest.

\section{Literature Review}

The current Global scenario has shown the fundamental and cyclic faults in the economy and industries of many of the countries where India too stands strong. Until the scenario changed to almost an apocalypse around the globe, India did maintain a very good guiding power for its industrial developments. According to an article posted on Seeken.org, India is one of the fastest developing countries but is still a developing country even after 60 years of its independence. (source: Seeken.org)

Being a developing country and facing such a big pandemic can play a tough game with the survival of the economy and can push the nation back a few pages. This paper tries to focus on the steps a nation can follow to come up with a new start-up during such a pandemic with no fear or can keep the already running industries going to a complete stop, especially in a nation as populated as India.

The Effect of COVID-19 has shown devastating figures for the markets, talking specifically about the FMCG sector, they have fought hard to survive the pandemic lockout. (source: Trade Promotion Council of India). According to Economic times, it is a playing situation for every player in the market. Whoever plays hard wins the pandemic.

Not only just the Food and Beverages but the Health care services have also got a hit, the sector lacked the numbers of individuals to work and a loss in the demands as the people were trapped in their homes.

\section{Effect of COVID-19 pandemic}

Looking over the performance of the products of the different segments like beauty products, health care products, food and beverages, and various more, over the past few months ever since the lockdown was implemented by the Government is varying products to products.

According to The Trade Promotion Council of India's (TPCI) article published in Economic Times, a 15$20 \%$ rise in the demand was witnessed in the food categories like confectioneries, sweets, organic processed foods and a $100 \%$ spike in the demand of essential commodities like rice, wheat, and pulses.

Corona Virus not only impacted the demand for food items but also the demand for hygiene products. Demand for hand sanitizers and liquid soaps was high to $400 \%$, as said by the article in the New Indian Express. Whereas there is a decline in the demands of beverages and snacks, according to an earnings statement by the New York-based beverages and snacks maker, PepsiCo and Lay's snacks sales have fallen to a double-digit in India viz. the beverage volume declined $25 \%$, as showed by an article in Economic Times.

The consumption of liquor and spirits has seen an overall decline of $15 \%$ globally. The sales of the liquor in the Indian market in terms of volume has gone down by $35-40 \%$ in the current year because of the COVID cess and implying a ban on the sales of liquor on-premise bars and restaurants. It was expected that there will be some recovery if the restrictions would be taken out, as India reports to be 3rd largest liquor market in the world with an annual sales value of $\$ 35$ billion. But as the restrictions were taken out, the State Government imposed Covid Cess on liquor sales beyond $60-70 \%$ and sales started declining (sourceFinancial Express).

Even though some of the segments have seen a very huge rise in the demands for products and others have seen the struggle, but the journey has been the same for every segment. As the one which did not have demand were struggling for demand and those whose demands were high, they struggled to meet the production capacity to fulfill the demand in the market due to unpreparedness and lack of labor to complete the task in the required minimum time frame. 


\section{Impact of coronavirus on the Indian healthcare system}

The healthcare sector is one of the most impactful structures to take a hit because of this unpredictable global pandemic challenge known as "Corona Virus" and the pandemic is likely to cause a huge dent in the cost, revenue, and profit to the health sector. To overcome this, private hospitals from every part of the country along with small private clinic, are extending a helping hand to the government by providing different types of medical equipment, space for isolation wards, and their staff to increase the workforce, even after all this, the health industry in India is bound to face challenges. To overcome the challenges, hospitals have decreased the non-important surgeries, limit the number of international patients, and OPD footfall.

This sector is facing most of the challenges because of the following reasons (EH news bureau, 2020):

1. It is investing in additional manpower, equipment, consumables, and other resources to ensure 100 percent preparedness for safety in the hospital(s) and eventual treatment of patients if needed.

2. And on the other hand, it is experiencing a sharp drop in OP footfalls, elective surgeries, and international patients.

The industry has been experiencing a great loss of its existing business and profit and this trend is expected to continue for the near future for at least 3-6 months, and most of the sector's costs are fixed, it is expected that there will be losses and severe impact on cash flows.

Some of the things which this sector requires to overcome the situation are:

1. The private healthcare sector needs indirect and direct tax benefits, and fixed cost subsidies from the government to address the problem and overcome the situation.

2. It is important to look at this industry favorably, whenever the government announces any fiscal changes, which will give them benefits in the form of relaxations.

3. The industry is also likely to benefit from increasing awareness about healthcare and the more government focus that this endemic is likely to result in.

Impact on the medical devices industry (Srinidhi Ramesh,2020)

Our country is importing most of its medical products such as consumables, disposables, and capital equipment which includes orthopedic implants, gloves, syringes, bandages, and MRI scanning devices from China. Due to the current crisis and the political tensions between India and China, medical equipment manufacturers across India are finding it difficult to source important raw materials and electronic components from Chinese factories.

Even though some of the factories in China have started their operations and started the manufacturing of some equipment, a shortage of some raw material still exists because of the limited trade between the two countries due to political tensions. This is badly affecting the margins of the total sales and profitability of Indian companies who are importing medical devices and small electronic components from China to manufacture finished products. This can also put upward pressure which will result in an increase in the prices of medical devices for a short period.

Impact on pharmaceuticals (Srinidhi Ramesh,2020)

Pharmaceutical drugs that are made in India are known for their quality standards across the whole world and are exported to developed economies such as the USA, Canada, Germany, etc. However, the Indian pharmaceutical industry is facing fierce competition from its rival China because of the cost advantages that China enjoys in its product. However, the sector is expected to come to its original position soon as the government lifts the restrictions and it extends their full support to give some kind of benefits.

Also, China is resuming its drug production and it will most probably increase the supply chain as India is importing $85 \%$ of pharmaceuticals ingredients from China but it will also result in an increase in competition as China also exports most of its medicines across the world.

FMCG during the pre-COVID world - (Dr. Yogesh D Mahajan, 5-sep-2020)

The Indian FMCG market has developed rapidly After mid-2018 the market saw good growth, but the growth rate started falling rapidly to roughly one half by Jan-Feb 2020 over the past 15-19 months, the situation was going rough on the market so the FMCG companies tried to bargain expecting an increase in the market share by lowering the price and selling customers higher supplies. In the Urban parts of India in particular, but the rural parts of India cannot be overlooked. As late in the rural part of India, the growth of the FMCG market has been more than the goods market, which accounts for over 40 percent of FMCG total sales in India, and the rural sector is an upcoming force for the industry with a $12 \%$ of world's population are 
in Indian villages. To target the lower incomes of people in rural India the FMCG companies introduce smaller packages of the products to improve the presence of the rural parts, it is a proper figure of how companies try to implement new development plans. Because of the unbalanced bargaining power and selling capacity of Kirana stores, Kirana stores suffered a lot because of the western trading and ordered exchange. This situation will improve, as steps have been taken to digitize Kirana shops so that they can interact with a larger group of retail partners. This improves the overall market balance throughout the country.

Post-Covid FMCG market in India - (Dr. Yogesh D Mahajan 5-sep-2020)

After the Covid pandemic hit the market the condition of the market drastically changed. In India, after the Covid-19 outbreak, there is an exponential demand for hand sanitizers and health, hygiene products, the current year 2020 is anticipated to have the highest growth of these products. On the other hand, more than 600.000 Kirana outlets might have been shut down because of the lockdowns as maintaining business was not possible for most store owners. the returning of shop owners to their villages thinking that shops won't reopen. According to the records of Parle, goods had to close down in April-May roughly 10\% of the 5,7 million Kirana stores which used to sell tea from the home and road corners. The head of Parle category B has claimed that distributors have lost their own money from the channels. "All of these channels may completely have been taken down. Also, 1 to $2 \%$ of the largest shop chain have been shut down, the owners of shops going to their villages and this will remain same for 6-7 months. While some might reopen, the scope of businesses has been impacted by the closing of small Kirana. The gradual reopening of most retails may happen. While Kirana stores are limited for a longer period. . Sunil Kataria, Chief Executive Officer of Godrej Consumer Goods India \& SAARC, hopes that the closing of shops is temporary even though the period is unsure. There are 10-12 million small retail outlets selling food and other quickly shifting consumer items in India, but many are fractional and in the hinterland. There is a fall of $34 \%$ in the FMCG industry shares in April, contributing to a $38 \%$ decrease in the sales in small companies, while modern trade reported a $5 \%$ growth.

Therefore, here are a few of the points we noted which can be helpful for business purpose in the future and to run the operations smoothly in times like this even in the coming years.

\section{Objective of the Study}

As the world is moving towards a phase that no one expected, things are not in the hands of humans anymore. Countries have suffered a huge rate of COVID cases, death rates, and a loss to their economy. But among all that the industries which were blooming or were about to fly high have got the worst hit by the COVID-19.

Industries are the main and major driving source that is fulfilling the needs of its consumers and on another hand, they help in contributing to the economy. But what happens when this huge driving force stops or gets to a halt, things will start to fall apart and the situation won't be normal anymore.

Therefore, to be prepared for the sudden challenges that might come in the future just like Corona did, it is important to get prepared for it from the very lesson we have learned from the current scenario. The main and major objective of this study/research is to dive deep into the FMCG sector and determine which segment has got the worst hit during the epidemic. What is the condition of the Indian FMCG sector at this period, and what all measures can be taken to revive the sector?

Which product can perform better in the market? which product's performance has dropped in the pandemic? which product can give a ray of hope to the FMCG sectors? These are a few questions raised in the mind while working on this research, and it became an objective to find an answer to all these questions with the help of pertinent market data.

\section{Research Methodology}

The paper tries to study and analyze the current FMCG sector scenario in India and helps to prepare the reader and us to be ready for any situation similar to COVID-19 and not affect the operations of the business. The study has been done majorly by using secondary data to analyze the FMCG sectors. The data has been collected from various sources such as, research papers, articles, news, blogs that have been published in India using the Indian data for the FMCG sector of the Indian market. The Geographical scope 
for this paper is India. The paper will be telling about the effect of COVID-19, the effect on the healthcare and FMCG sector getting affected. Let us look into the topics to get more clarity.

\section{Sampling Design}

A sampling design is a plan to get the samples from the targeted sampling audiences or sampling frames, sampling design is a kind of procedure that a researcher adopts to select some precise sample from the list of responses they have received. The research was conducted from a specifically available pool of respondents. Therefore, the sampling technique we used in this survey was the convenient sampling technique.

\section{Data Analysis and Interpretation}

To come up with a robust and effective business plan we needed to know the choices, preferences, and behaviors of the consumers from different parts of the society, genders, and ages. Only then we can create a business plan when we can target the entire audience demographically. We conducted the survey and circulated the form to various parts of India to get a precise report. The survey was done to study the Indian FMCG market along with the Indian consumer's preferences among the different varieties of segments targeted in the FMCG sector. The reading is purely based on the responses that we received through the survey. The graphs are explained below.

The survey consisted of the different questions targeting the thinking of the consumers at the time of pandemic on FMCG's various segments, the questions were based on gender, age, living criteria, and what consumer's demand from the Indian FMCG units.

\section{Preference of Packed Food/ Drinks according to the Gender}

The effect towards any products depends on what one thinks and how, the way the genders differ, the same way their way of thinking or perception also changes. Therefore, to know the preference of people based on their gender and what they think, the study was conducted to be of good help in coming up with more efficient solutions over which gender to target for which category/ segment of FMCG.

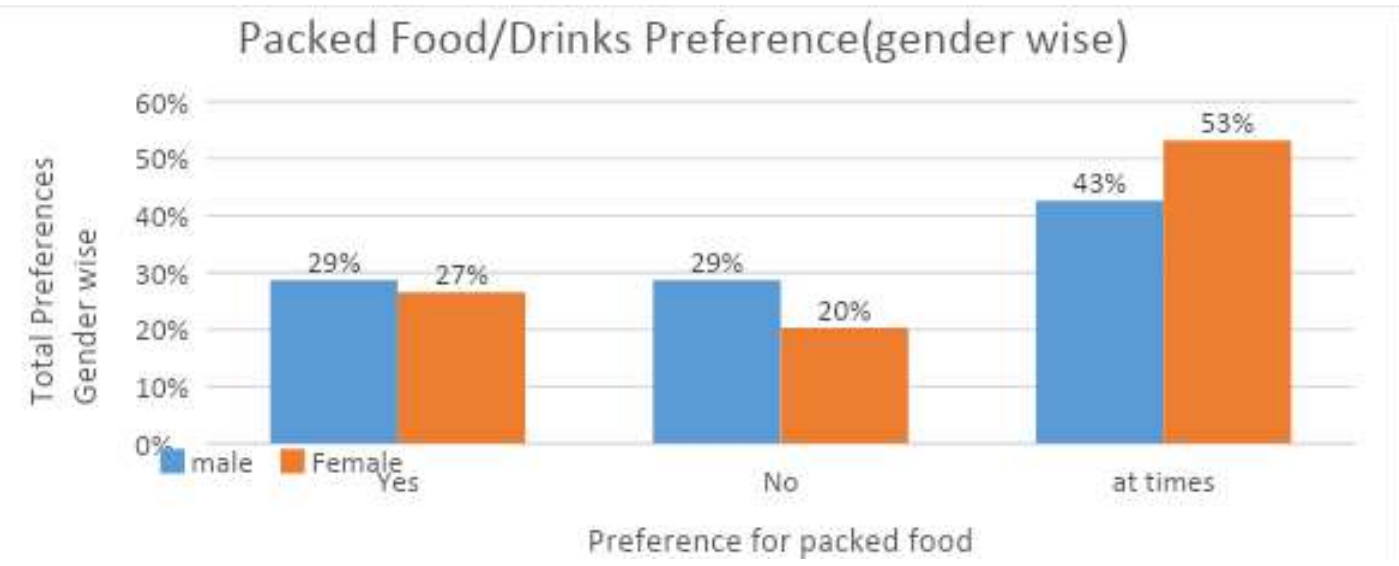

Figure 1: Packed food and drinks preference of different genders

The graph above holds the data for the preference of the Consumers for the packed food and drinks. Based on the data what we can take for the Packed food and drinks is that the demand for the packed food and drinks is more fluctuating towards all the answers. Around $29 \%$ male and $27 \%$ females believe that they prefer the packed food and drinks, $29 \%$ of Males and 20\% of females believe that they don't need packed food or drinks no matter what the situation may be, whereas about $43 \%$ of Males and $53 \%$ of Females think that they can switch to packed food or drinks at times, which means if the situation demands they would be having no objections in consuming the packed food or drinks.

\section{The preference also shifts based on the age of the consumers}


Therefore, it was important to target the respondents based on their age. Having data for the age-wise preference of the respondents and consumers would allow understanding what thoughts the consumer having different ages are having towards the segment.

The graph below represents the data of the consumers based on the different age groups of the respondents and what are their thoughts over the asked segments of the FMCG.

\section{Packed Food/Drinks Preference(age wise)}

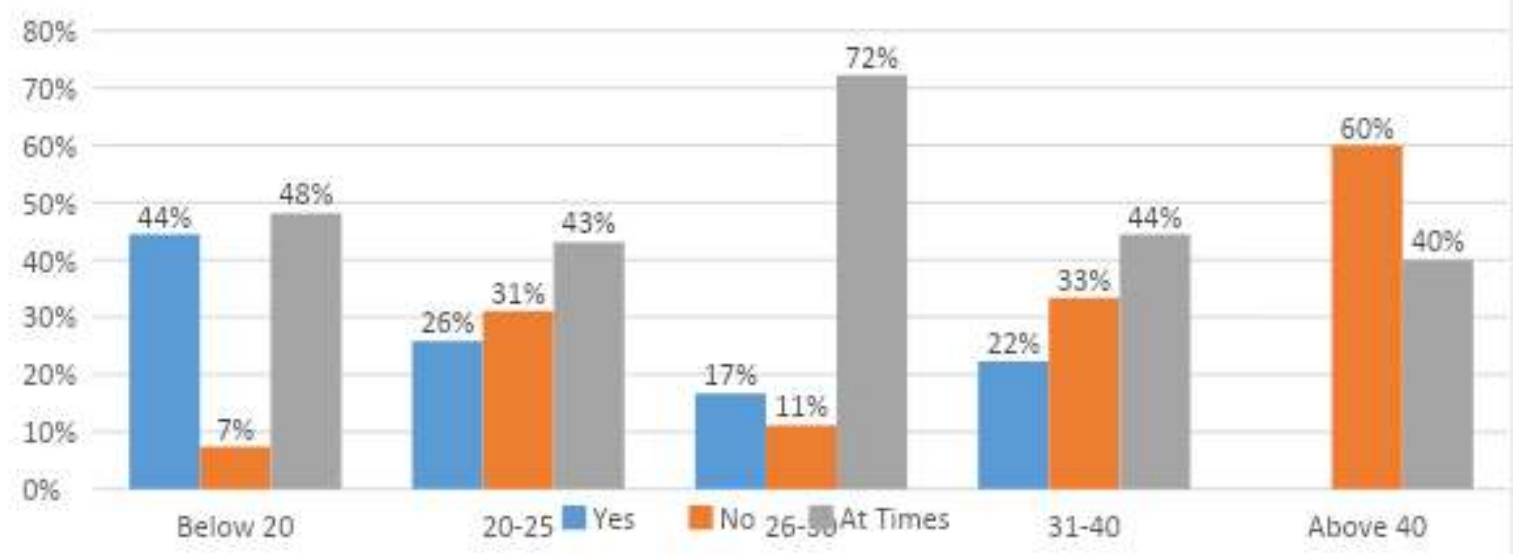

Figure 2: age-wise preference for packed food and drinks

The data above concludes that the majority of the people who like packed food and drinks the most fall in the category of below 20 age group, as the maximum responses we can see on that category is for yes i.e., 44 $\%$ of the respondents below 20 prefer the packed food and drinks and about $48 \%$ of the respondents feel that they can prefer or switch to packed food and drinks if the situation demands it whereas only $7 \%$ of the respondents feel that they don't prefer the packed food or drinks. If we take the 20-25 age group under consideration, we can see that the graph is rising all the from 'yes' to 'at times'. About $26 \%$ of the respondents feel that they do prefer packed food or drinks, $31 \%$ feel that they don't prefer the packed food and drinks whereas, $43 \%$ of the respondents feel that they can shift or prefer packed food at times when the situation demands it. The age groups of 26-30, 31-40, and above 40 are having the least interest in the packed food and drinks whereas a maximum of the respondents of this category feel that either they do not prefer the packed food and drinks or they might shift towards that category at times looking at the situation. Taking the soft drinks under the consideration, the market for the carbonated and non-carbonated drinks industry in India was expected to grow 45\% annually in 2014 (Dr. Satnam Ubeja and Ranjana Patel: Consumer preference towards Soft Drinks: A perceptual study, Pacific Business Revie International Vol 6, Issue 9, March 2014). The prediction of the market growth and the actual growth of the soft drink market has been increasing drastically. The market may continue the robust growth trajectory it has, as the annual capita bottle consumption is expected to reach 84 by 2021 according to the PepsiCo India bottling partner Varun Beverages Ltd (blog.drinktec.com).

Taking the growth factor under consideration the companies must have a robust strategy for the different age group consumers and gender-based consumers to tackle the situation like COVID-19 smoothly.

FMCG's Food and Beverages segments include a vast category of food items under their belt, taking the food segment under the consideration at the moment, at the time of pandemic when everyone was forced to stay inside their houses might find packed food or meals ready to eat most preferable for them. Let us find out the same with the help of the graph and see it is preferable for them or not. 
Food Preference for Males- Preference for the food changes according to the gender of the consumers also, the more health freak consumer will be more directed towards the home-cooked meals and away from the packed food or meals ready to eat. But preference does change when the situations are tough to manage.

\section{Food Preferences (Male)}

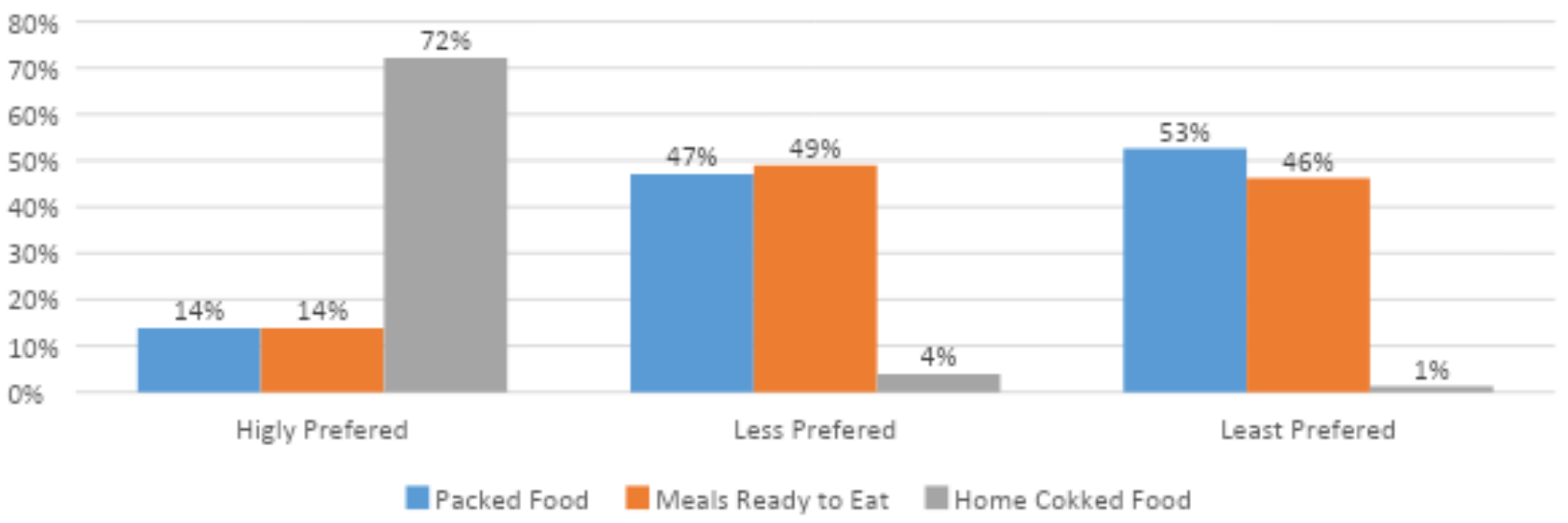

Figure 3: Food preference of Males

From the graph of preference of food for males we can say that majority of the males i.e., $72 \%$ of the males highly prefer the home-cooked food whereas for Packed food and MREs the percentage is same for both i.e. $14 \% .47 \%$ of the males preferred the Packed Foodless and it is least preferred by 53\% of the males, whereas $49 \%$ preferred MREs the less, and it was least preferred by $46 \%$ of the male respondents. From the graph, it was clear that the majority of the male respondents are preferring home-cooked food. Let us look at the response of the female respondents also and conclude a result after.

Food Preference for Females- Home-cooked food was preferred more by the male respondents, let's see what is preferred by the female respondents at the time of the pandemic. The graph shows that for female respondents also the preference for Home cooked food is much higher than that of the other two categories, about $69 \%$ of the female respondents highly prefer the home-cooked food, whereas about $9 \%$ highly prefer the packed food and $22 \%$ prefer the MREs. The majority of the female respondents i.e. $57 \%$ of respondents prefer the packed food less and 53\% preferred it the least, and MREs were less preferred by $43 \%$ of the respondents and it was least preferred by about $42 \%$ of the female respondents. Knowing the preference of all the genders for the food categories is important to launch the food product in the market. From the graph, it can be seen that the majority of the consumers prefer the home-cooked meal most, which gives us an idea that consumers are more directed towards the safety which they can get in home cooked meals. The choice of the food with health claims depends on the personal relevance and interest in healthy eating, (Caterina Contini: Some like it healthy; Can Socio-demographic Characteristics serve as predictors for a healthy food choice? Università Degli Studi di Firenze, Florence Italy). The preference of the consumers might change demographically, therefore having the respondents from the different parts of the country can help to create an effective strategy which can cover the consumer that differ from each other in all terms. 


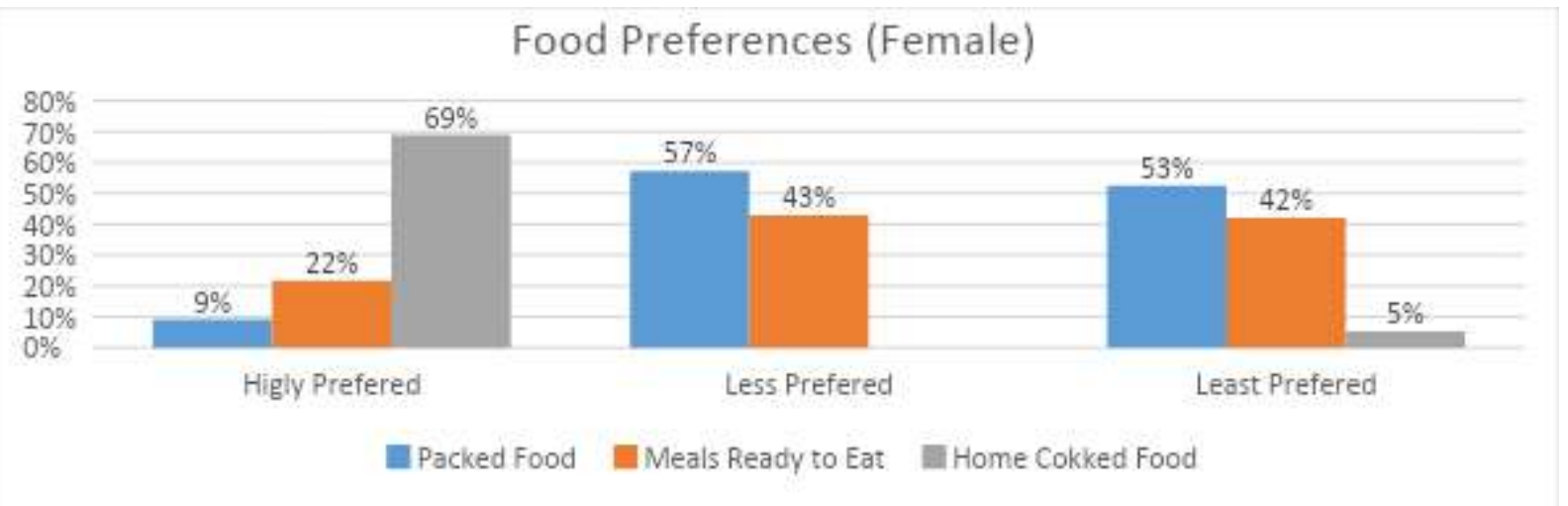

Figure 4: Food preferences of Females

The food preferences and the convenience of the food that the respondents may consume also depend upon how and with whom the respondents are living. Those who would be staying with their families regardless of they are working or not might feel that home-cooked food is more suitable for them than packed food, but if we look at the respondents who are living alone and away from their friends and families, then the convenience and preference might change as for those who are living alone and are working the quick and fast method seems to works better than preparing the whole meal thrice a day and that too regularly.

\section{With whom the respondents are living?}

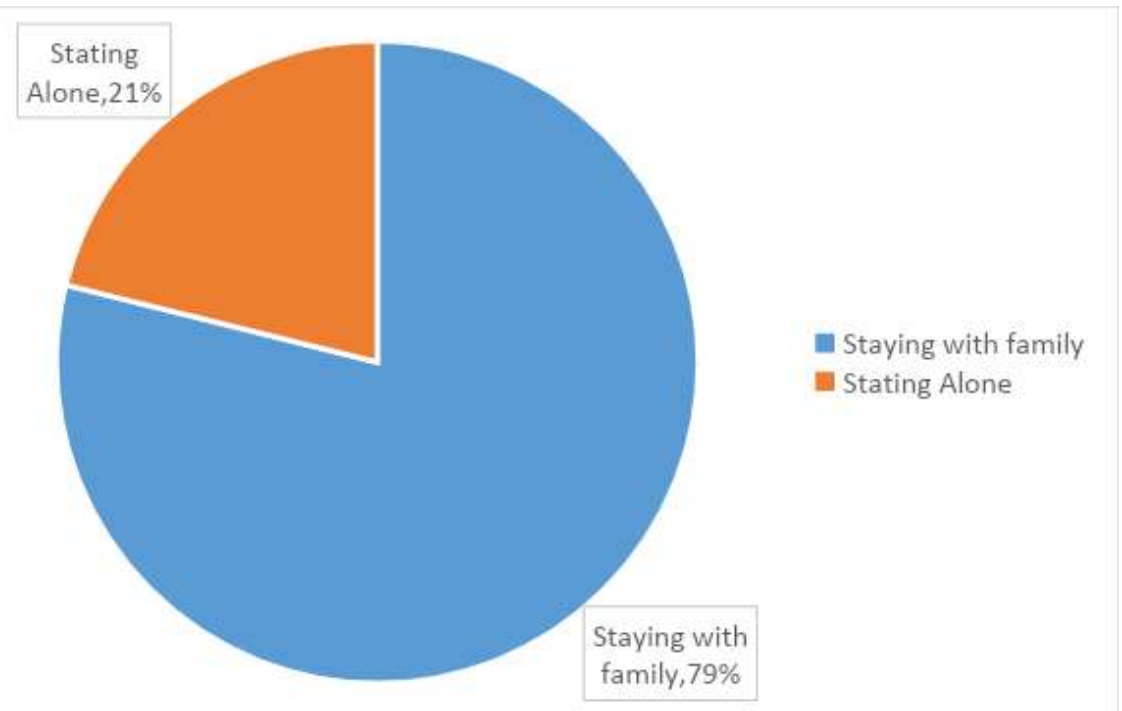

Figure 5: where respondents are living

Out of all the 175 responses we got on our survey, the pie chart above concludes that $21 \%$ of the total respondents are living alone whereas for the respondents living with their families are much higher i.e. around $79 \%$ of the total respondents are living with their families. It is very important to know how and with whom the consumers are living because that can give a brief idea about the result that we have got. And also it can give a chance to focus on both sides of consumers and treat them equally with their needs and demands.

Till now we have understood the preference of the consumers and also we have dealt with the reason behind why and what factor can affect the food consumption of the consumers, the same way the convenience is also affected for the consumers, taking three segments for the study which are Packed food, MREs and Home Cooked Food, we will be discussing the convenience factors for the consumers further. The convenience for the foods is done gender-wise, knowing the preference of both the genders would help the study to boost with a more precise idea to formulate the strategy and how to implement it at the hour of 
need. Convenience is one of the most important factors for a product to be bought, nobody purchases a product knowing that it might not be convenient for them to buy, a person living at very cold region might not be interested in buying cold drinks as it is not convenient for him/her. This way the convenience for people changes be it on the geographic location or what their needs, choice, and demands. Therefore, let us look at the graph for further discussion over the convenience part of the consumers.

\section{Convenient food for the males at the time of the pandemic}

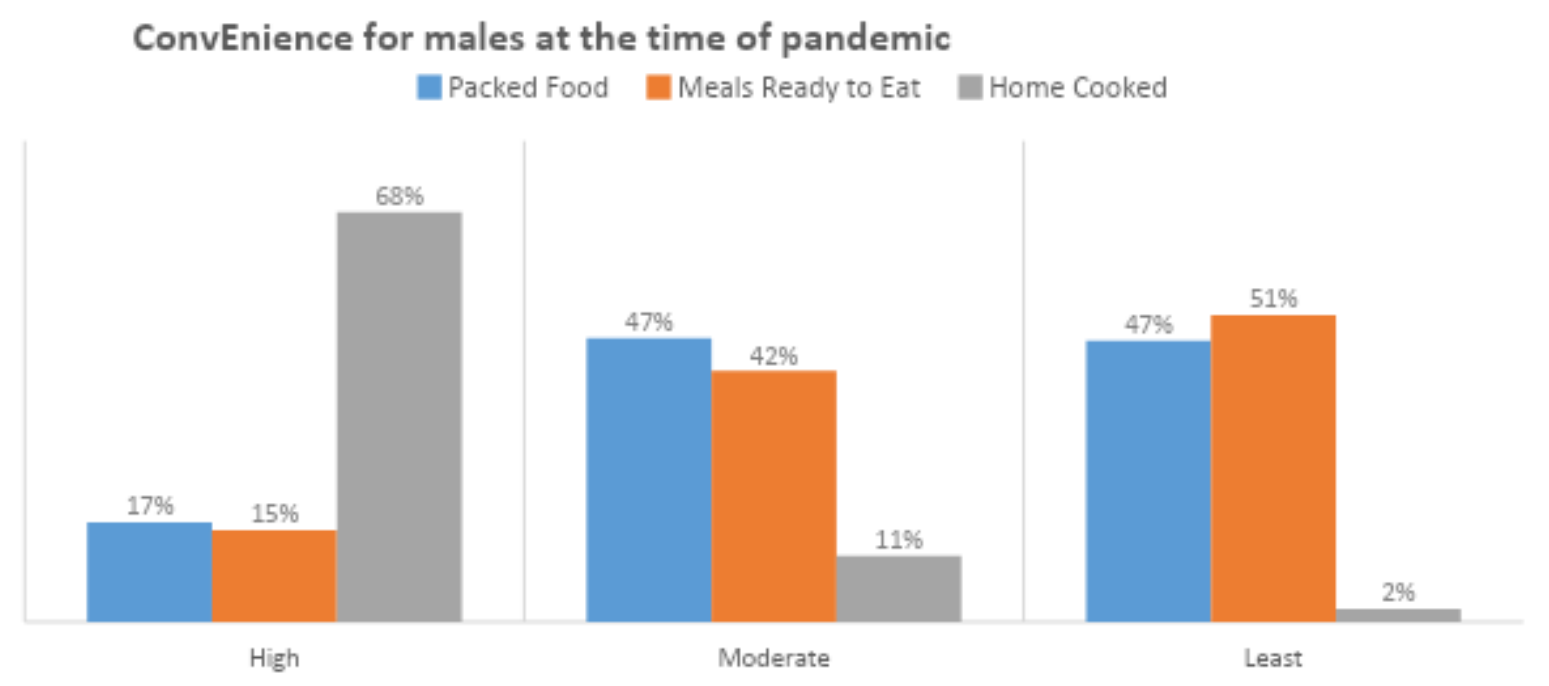

\section{Figure 6: Convenience of Food for males}

From the graph above we can say that the rush for home-cooked food is pretty much higher, as $68 \%$ of the male respondents' feel that home-cooked food is highly convenient for them at the time of pandemic whereas for $11 \%$ it is moderately convenient and least convenient for $2 \%$ of the respondents. $17 \%$ of respondents feel that packed food is highly convenient for them, $47 \%$ think that it is moderately convenient for them and least convenient for the other 47\%. Taking MREs under consideration, 15\% find it highly convenient for them, $42 \%$ feel that it is moderately convenient for them and it was least convenient for around $51 \%$ of the total respondents.

In the case of males we found out that Home cooked food was highly convenient for the consumers, now let us look at the case of female respondents, and what is more convenient for them.

\section{Convenient food for the females at the time of the pandemic}

From the graph we can conclude that around $69 \%$ of the female respondents found that home-cooked food was highly convenient for the $6 \%$ found it moderately convenient and it was of least convenience for about $3 \%$ of the female respondents. Whereas $19 \%$ found packed food and $12 \%$ found MREs to be highly convenient for them, and $48 \%$ found Packed food and 46\% found MREs to be moderately convenient for them at last $43 \%$ and 54\% of the female respondents found Packed food and MREs to be least convenient for them respectively. According to Life Sciences Medical News, and research conducted in Germany and Belgium, the research survey demonstrated that the Coronavirus (COVID-19) having the adverse effect one was on people's eating habits. The food consumption was increased, which means either the canned food would be having higher demand in the market or the people would be buying more and more of the vegetables and fruits and filling up their ration stocks. Either way, the consumption of food is still on the run. Knowing the convenience of the people over food items it can get easier for the companies to come up with products that can help people save their time according to their health requirements and convenience. Where nothing can be compromised for both parties. 


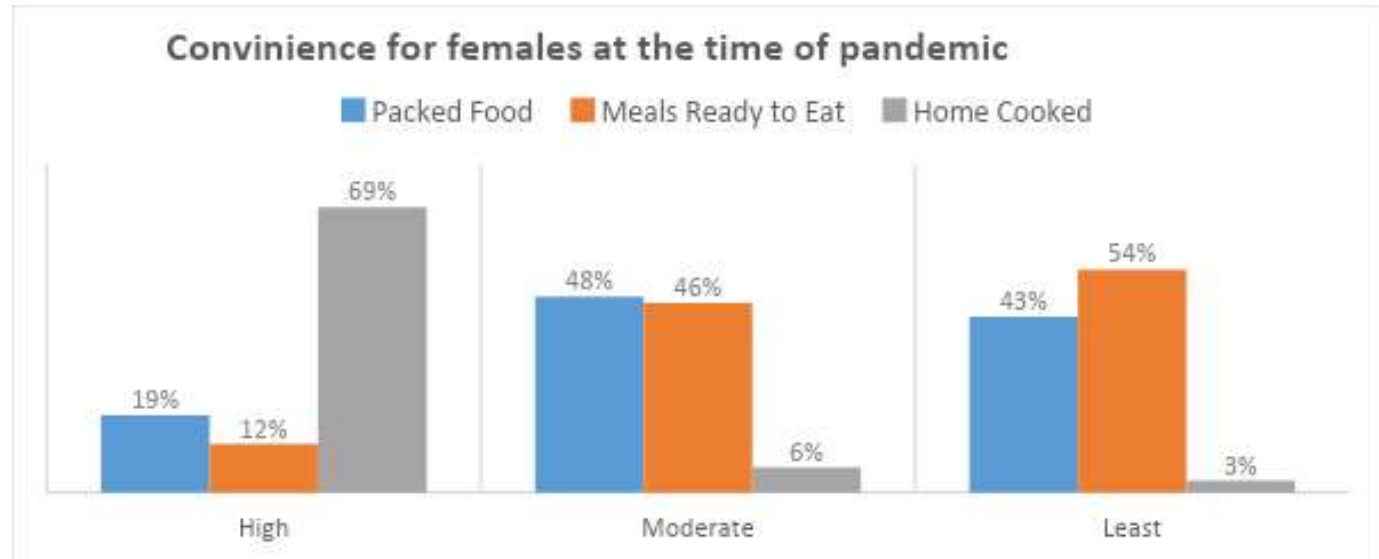

Figure 7:Convenience of food for Females

As discussed earlier the convenience might be depending upon where the person is living and with whom, what is the age of the respondents, and what are their needs have to be fulfilled, next we would be looking at the convenience of the people based on their age groups. As the age gap between the consumers affects the product very much. A younger person using costlier supplements can be a need for them but for a person who is very much aged, it can be a total waste of money as they have nothing to do with gaining weight and rushing the gym. In the same way, the food preferences and the convenience changes from person to person of different age groups.

\section{Convenience at the time of pandemic for different age group respondents.}

The survey questionnaire included various questions for different genders and different age group respondents. The age group which was included in the questionnaire was the following- Below 20, 20-25, 26-30, 31-40, and Above 40. The highest number of the respondents we got were from the age group of 2025 and Below-20. Therefore, let's look at the graph for further discussion.

The graph below shows the result for the convenience at the time of pandemic and from the graph below it can be seen that the highest number of respondents are from the age group of 20-25. Therefore, taking this group under consideration we can say that, about $90 \%$ of the respondents of this age group feel that homecooked food was highly convenient for them at the time of the pandemic, $8 \%$ found it to be moderately convenient and $3 \%$ found the home-cooked meal to be least convenient. For packed food, it was highly convenient for $23 \%$, moderate for $40 \%$ and $37 \%$ of the respondents felt it was least convenient for them. Also, around $38 \%$ of the respondents found that MREs were moderately convenient for them highly convenient for $19 \%$ and $43 \%$ found it of least convenience. 


\section{Convenience At The Time of Pandemic (age wise)}

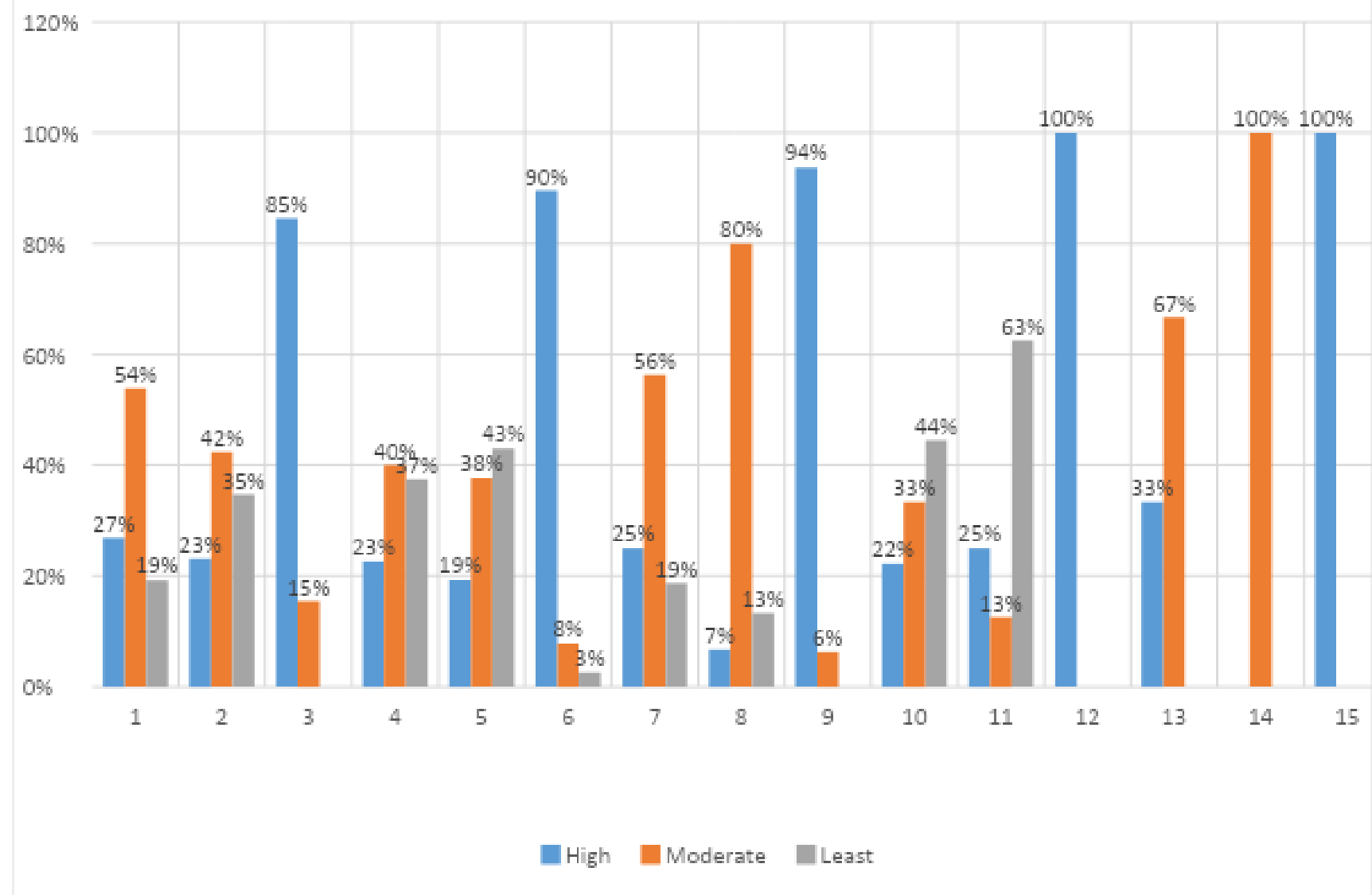

Figure 8:Convenience at the time of pandemic fro different age groups

Taking the other age group under consideration, the respondents under the age group of 31-40 and Above 40, the majority stands with the home-cooked food i.e. $100 \%$ respondents of both the age group feels that home-cooked meal is convenient for them. Under 31-40 age group packed food is highly preferred by $22 \%$ of the respondents, moderately convenient for $33 \%$ and least convenient for $44 \%$, same age grouped respondents, where $13 \%$ found MREs to be moderately convenient, highly convenient for $25 \%$ and least convenient for the remaining $63 \%$ of the respondents. For Above 40 age grouped respondents, MREs were highly convenient for $0 \%$, moderately convenient for $100 \%$, and least for $0 \%$, Packed food was highly convenient for $33 \%$ and moderately for $67 \%$, here $0 \%$ of the respondents found packed food to be least convenient.

As the virus outbreak happened, the word immunity started to flow high in the minds of the consumers, they still were attracted to their favorite snacks but now they wanted to shift towards something healthier and more diet freak which should not have any adverse effect on their health and make them prone to the virus (Food Navigator-Asia: from convenience to conscious).

As convenience can shift during the pandemic for better health, the same can happen with the buying habits of the consumers, what they used to buy before the outbreak of the virus and what they started purchasing during the pandemic, and to which segment they will be directed after the pandemic. This factor is also important to consider because it can help the companies to form a strategy looking at their consumers throughout the path they choose and travel.

Ali Webster director of research and nutrition communication at IFIC answered the questions about what excites the people on the new year. According to their survey, 29\% looked forward to catching up with their friend and eat, $27 \%$ were not that much worried about the shopping for groceries and other items and dining while $23 \%$ cited going out to restaurants more often after they received the first dosage of the COVID-19 vaccine. (Food Navigator-USA). The same can be said for the food buying habits of the people, it can change with time or after the consumer receive their first dosage of the COVID-19 vaccine. 


\section{Bought Products during the Pandemic}

From the graph above it is visible that consumers of all the age groups were focusing more and more towards their health, as we can see in the graph the highest majority if for immunity boosting products, antibacterial products, and self-prepared meals. Taking the 20-25 group into consideration, around 46\% felt that immunity-boosting product is a necessity for the $48 \%$ felt the necessity for antibacterial products, $25 \%$ felt the necessity for packed food and beverages, while self-prepared meals were a necessity for around $78 \%$ of the respondents. The same goes for all the other age group respondents.

\section{Bought products during the Pandemic (age wise)}

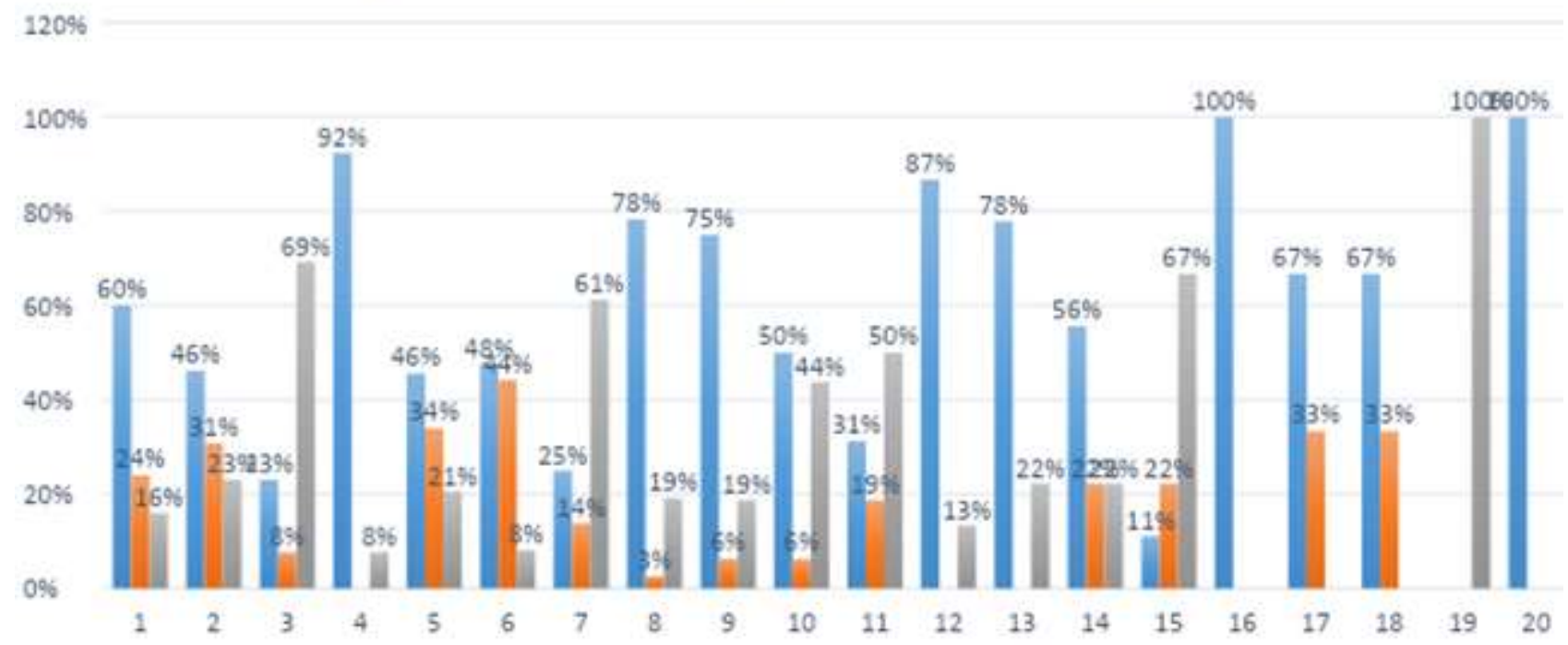

플 Necessity $\mathbf{E}$ Never used $\mathbf{E}$ Can adjust if Unavailable

Figure 9:Products bought during Pandemic of different age group

Every aged group person felt the necessity for immunity boosting products, antibacterial-products, and selfprepared meals. The graph concludes that the population is more directed towards their and their family's health more than the taste. Knowing what the consumers are up to can help the study and companies to formulate a strategy that should directly affect the choice of the consumers over their purchasing habits and what they wish to purchase in the future.

\section{Categories of FMCG Bought during a pandemic.}

Determining the categories that the consumers are purchasing heavily was important, as knowing what the consumers are up to will give you time to get prepared even for the worst-case scenario. The companies or even the start-ups that are now starting to fly but due to the pandemic they were forced to land on the ground can also consider this point to grab more of the profit side and be a constant player in the market. 


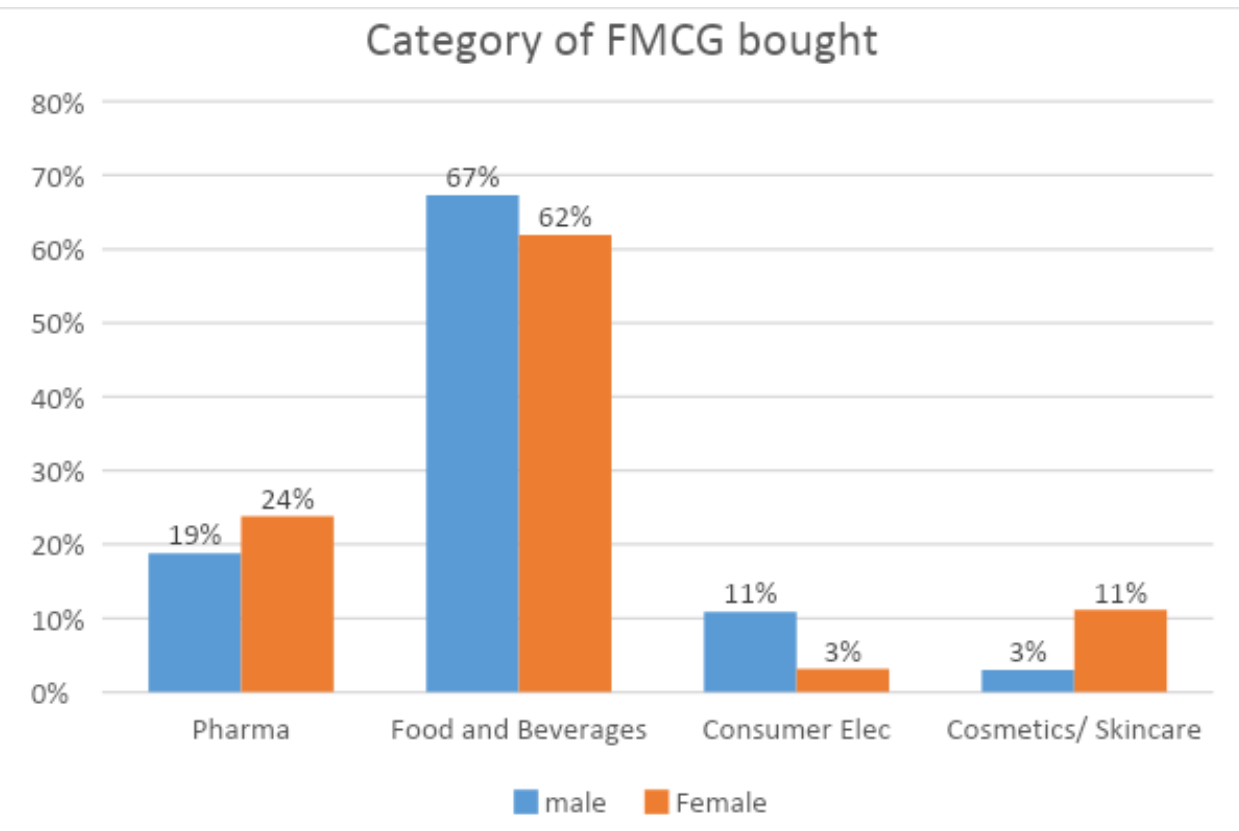

Figure 10: Categories of FMCG bought by both Males and Females.

The graph above suggests that at the time of pandemic if a company is focusing more and more on the food and beverages and Pharmaceutical segments of FMCG, it might result as a positive outcome for them in gaining the revenues, looking at the data we can say that, maximum of the population was concern towards stocking up the ration supply for having a smooth lockdown period. $67 \%$ of the males and $62 \%$ of the Females were focused more on the food and beverages, whereas $19 \%$ of the males and $24 \%$ of the females focused on the pharmaceuticals segment of the FMCG. Where consumer electronics and cosmetics/skincare stood for the lowest attention at the time of the pandemic.

\section{Delivery apps used by males and females during the pandemic}

Delivery Apps Used

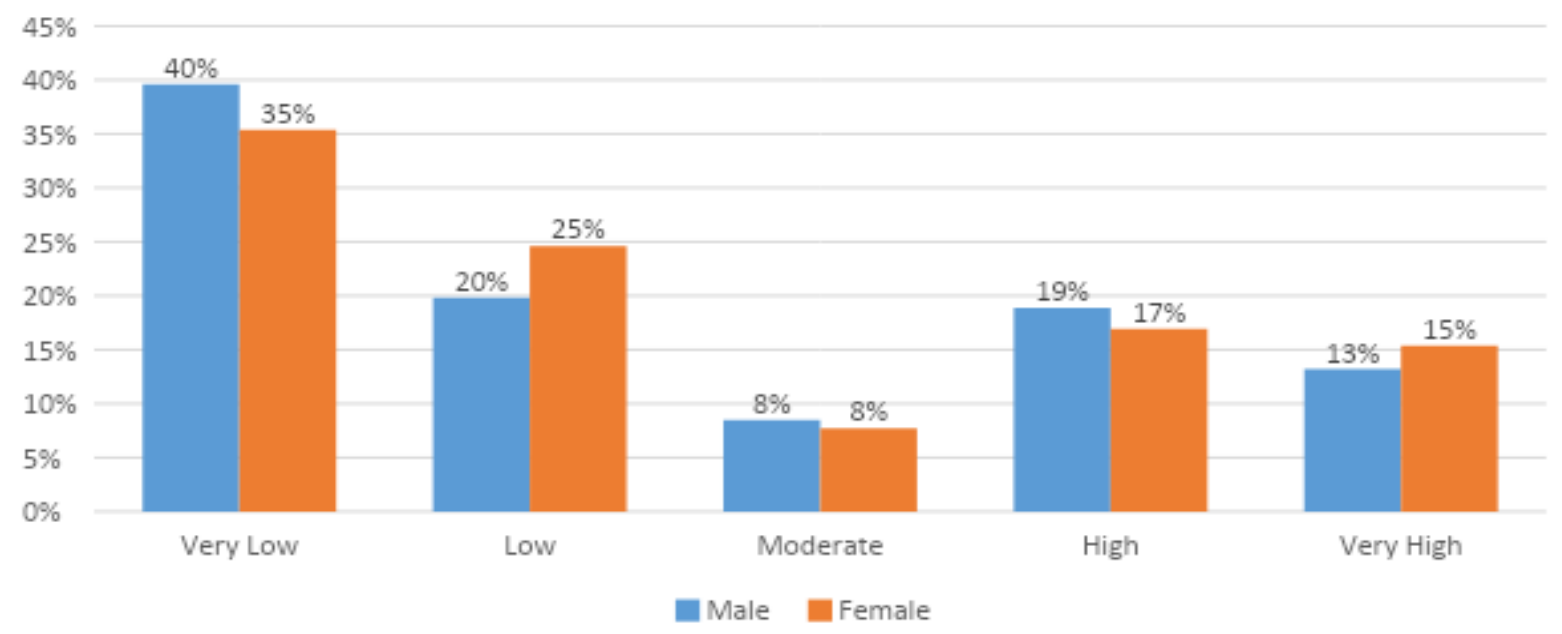

Figure 11: delivery apps used by males and females at Pandemic

As the fear of COVID-19 went to peak, more and more of the consumers wanted the products to be delivered art their door-steps, without any fear of spreading the virus. Therefore, to come up with the delivery model companies need to know if there are a sufficient number of consumers who are demanding the delivery of their groceries, as per the guidelines social distancing was to be maintained at any point in time.

It might not be a wise step taken by any firms or organization if they roll out any new decision knowing that the demand for that in the market is very low. From the graph, it can be seen that the usage of the delivery apps used by the consumers at the time of pandemic is very low, where $40 \%$ of the males and $35 \%$ of the 
males stand at the very low usage of delivery app side. And $13 \%$ of the males and $15 \%$ of the females said they have used the app to a very high extent. Therefore, the companies can take those consumers under consideration who have used the delivery apps and should come up with ideas where they can also attract those consumers who have not used the delivery apps at the time of the pandemic.

\section{Conclusion}

This study is a sincere attempt to look at and understand the Indian FMCG sector along with the preferences of the consumers towards the industry and what forces drive their preference to purchase a category of FMCG goods for their use at the time of the pandemic. The study also holds an intention to prepare a business plan for the Indian FMCG industries so that they can easily tackle the uncertain situations faced during the COVID-19 pandemic lockout.

The study is backed by the survey that was conducted by us to know the preference of the consumers based on gender and age factors. Through the survey, we were able to target 175 respondents all total. In this conclusion, we would be giving you a brief about the findings and the measures to be taken.

From the study we were able to get was, most of the consumers preferred home-cooked food at the time of the pandemic, few were there who wanted to be packed or meals ready to eat. The choice was also depending upon a particular factor, with whom the respondents are living. This factor affects the other factors directly, as a person living with the parents has to consume food that the whole family is consuming or preferring, whereas a person living alone or working will have a different opinion and preferences.

The main focus of the consumers at the time of the pandemic was to consume more and more healthy food and immunity-boosting products. The people were more focused on the ration and filling up the stocks and at the same time, they were ensuring that the purchased goods are having the properties which would be boosting their immunity making them safe from the virus and the other segments that the consumers focused were on the pharmaceutical products.

The main conclusion that can be drawn from the survey that we conducted was that the consumers are now focused more on their and their loved one's health. The consumers are diverting away from the product that they used to prefer much and we're consuming more and more, now they want to have a product with them which can have the surety for them to keep them safe from the spreading virus.

The majority of the people have spent their lockdown period and pandemic period by remaining inside their houses in fear of getting affected by the virus, therefore at this time the best way to reach out to the consumers would be providing them with the home delivery options for the groceries and other essential products where the health of the delivery personnel is closely monitored.

What can be done- as of the survey speaks for itself, the majority of the consumers are focusing more and more on health-related products. Therefore, coming up with a product that can assure the consumers of their health would be a good plan for the companies as the while basing for the business now is the trust for the healthier products.

Home delivery should be given more focus, with following all the safety measures and standards. The consumers were either buying heavily the ration to pile up the stocks for the availability at the hour of needs or they were purchasing the anti-bacterial, immunity-boosting products. Therefore, the main products to offer to the market should be of this segment as these have the highest number of demands in recent times.

The companies now should focus on the different customers based on the different needs they have, as the respondents we have of the age group of above 40 years were more focused on the healthier products, than the packed food and beverages. The majority of the respondents lying in the age group of 20-25, we're also focusing more and more towards the healthier option for their lifestyle. More the healthier products which can meet the levels of up to the home-cooked food can have the potential for giving you a robust market base, whereas focusing on the health-related products can be a much good option for the companies to generate revenues during the pandemic period as like COVID-19.

\section{References}

1. "Impact on the sales of Hand sanitizers" retrieved on October 15, 2020, from https://www.newindianexpress.com/business/2020/mar/15/coronavirus-impact-demand-for-handsanitizers-up-400-2116825.html

2. "Food and Beverages industry performance" retrieved on October 15, 2020, from 
https://economictimes.indiatimes.com/industry/cons-products/food/pepsico-india-beverages-andsnack-sales-fall-by-double-digits-in-the-past-12-weeks/articleshow/76945053.cms?from=mdr

3. "Performance of healthcare services" retrieved on October 21, 2020, from http://careeranna.com/

4. "Confirmed cases of Corona" retrieved October 7, 2020, from www.data.gov.in

5. Dr. Yogesh D Mahajan "Impact of Coronavirus Pandemic on FMCG sector in India", retrieved from research gate on October 16, 2020,

https://www.researchgate.net/publication/344139429_Impact_of_Coronavirus_pandemic_on_fast_m oving_consumer_goods_FMCG_sector_in_India

6. "Indian FMCG analysis" retrieved from https://www.ibef.org/industry/Fmcg-presentation October 2020)

7. Dr. Saraswati C "The impact of FMCG goods during a pandemic" retrieved on October 19, 2020, from https://www.xajzkjdx.cn/gallery/19-oct2020.pdf

8. "resuming the paused FMCG sector in India" retrieved from https://www.ijresm.com/Vol.3_2020/Vol3_Iss6_June20/IJRESM_V3_I6_113.pdf

(19 October 2020)

9. "Impact of lockdown due to COVID-19 outbreak" retrieved from https://www.researchgate.net/profile/Mansi_Pandit/publication/342074919_Impact_of_Lockdown_d ue to_COVID19_Outbreak_Lifestyle_Changes_and_Public_Health_Concerns_in_India/links/5f2eea ff299bf13404b12c9b/Impact-of-Lockdown-due-to-COVID-19-Outbreak-Lifestyle-Changes-andPublic-Health-Concerns-in-India.pdf (19 September 2020)

10. Dr. Arun Gaikwal " The impact of COVID-19 over Indian Economy” retrieved from https://www.researchgate.net/profile/Arun_Gaikwad2/publication/344217837_CORONAVIRUS_T HE_IMPACT_OF_COVID-

19_ON_INDIA_ECONOMY_Publication_CopyCORONAVIRUS_THE_IMPACT_OF_COVID19_ON_INDIA_ECONOMY_Publication_Copy/links/5f5cb00a92851c07895fecf0/CORONAVIRU S-THE-IMPACT-OF-COVID-19-ON-INDIA-ECONOMY-Publication-CopyCORONAVIRUSTHE-IMPACT-OF-COVID-19-ON-INDIA-ECONOMY-Publication-Copy.pdf $\quad(15$ November 2020)

11. Dr. Satnam Ubeja and Ranjana Patel (2014) consumer preference towards soft drink: A perceptual study (17 October 2020)

12. Preference of food: some like it healthy (Caterina Contini: Some like it healthy; Can Sociodemographic Characteristics serve as predictors for a healthy food choice? Università Degli Studi di Firenze, Florence Italy) retrieved from https://doi.org/10.1016/j.foodqual.2015.07.009 (3 ${ }^{\text {rd }}$ January 2021)

13. COVID-19 affecting the eating behavior of consumers retrieved from

14. https://www.news-medical.net/news/20210114/COVID-19-pandemic-negatively-impacts-eatingbehaviors.aspx (19 July 2020)

15. The convenience of the food retrieved from:

16. https://www.foodnavigator-usa.com/Article/2020/12/17/Consumers-will-seek-convenience-comforthealth-from-food-in-2021-as-they-await-return-to-normalcy (19 July 2020)

17. Conscious and convenience of Food retrieved from:

18. https://www.foodnavigator-asia.com/Article/2020/07/02/From-convenience-to-conscious-Covid-19pandemic-leads-to-shift-in-snacking-priorities-experts

19. Misbah Ehsan and Samreenlodhi (Vol 5, Issue 11 November 2015) Brand packaging and consumer buying behaviour: A case of FMCG products. (5 August 2020)

20. Tatiana Bonilla (2010): Analysis of consumer preferences towards $100 \%$ fruit juice packages and labels. (5 December 2020)

21. Decline in the sales of packed drinks retrieved from:

https://economictimes.indiatimes.com/industry/cons-products/food/pepsico-india- beverages- 
and-snack-sales-fall-by-double-digits-in-the-past-12-weeks/articleshow/76945053.cms?from=md $\boldsymbol{r}$ (visited on 10 November,2020).

22. Mary Loxton, Robert Truskett, Brigitte Scarf, Laura Sindone, George Baldry and Yinong Zhao, "J. Risk Financial Management. 2020, 13(8), 166; https://doi.org/10.3390/jrfm13080166 (consumer behaviour during crises) (10 December, 2020)

23. Buying behavior of consumers retrieved from "Martin O'Connell, Aureo De Paula, and Kate Smith: Preparing for A pandemic": https://repec.cepr.org/repec/cpr/ceprdp/DP15371.pdf (Spending Dynamics) (15 November 2020)

24. Himgiri Chaudhary "Analysing the Paradigm shift of Consumer Behaviour Towards E-Commerce During pandemic lockdown" (Usage of delivery apps during a pandemic): (20 December 2020) https://papers.ssrn.com/sol3/papers.cfm?abstract_id=3664668

25. Kaustuv Chatterjee, Kaushik Chatterjee, Arun Kumar, Subramanian Shankar "healthcare impact of COVID-19 epidemic in India" retrieved from https://doi.org/10.1016/j.mjafi.2020.03.022 December 2020)

26. Aman Jha "Resuming the Paused FMCG Sector in India" International Journal of Research in Engineering, Science and Management Volume-3, Issue-6, June-2020 ( $2^{\text {nd }}$ February 2021)

27. Indian FMCG market size retrieved from https://www.statista.com/statistics/742463/indiafmcg-market-size/ visited on 11 November, 2020

28. Indian FMCG Analysis retrieved from https://www.ibef.org/industry/Fmcg-presentation visited on 1 December, 2020

29. Effect of COVID-19 on retail in India retrieved from http://s3.ap-south-1.amazonaws.com/s3fs-public/2020-03/RAI\%20 visited on 1 December, 2020

30. Effect of COVID-19 on supply chain retrieved from https://www.thehindubusinessline.com/companies/covid-19-how-fmcg-sector-is-pulling-out-all-thestops-to-maintain-supply-chain-for-essential-products/article31482145.ece\# visited on 15 December, 2020

31. Contraction in Indian FMCG market amid COVID-19 retrieved from https://www.businessstandard.com/article/companies/india-s-fmcg-market-contracts-34-in-april-amid-covid-19-outbreak120052201706_1.html visited on 23 June, 2020

32. Impact of COVID-19 on the Indian FMCG sector retrieved from https://blog.smallcase.com/impact-of-covid-19-on-the-fmcg-sector-in-india/ visited on 20 November, 2020 